\title{
Dural Sinus Trombozu İle Seyreden Pediatrik Adenoviral Meningoensefalit Vakası
}

\section{A Case Of Pediatric Adenoviral Meningoencephalitis With Dural Sinus Thrombosis}

\author{
Bahri Elmas, Gökçe Genç, Taha Mansur Daştan \\ Sakarya Üniversitesi Tip Fakültesi Pediatri Anabilim Dalı, Sakarya \\ Yazışma Adresi / Correspondence: \\ Doç. Dr. Bahri Elmas \\ Sakarya Üniversitesi Sağlık Bakanlığı Eğitim ve Araştırma Hastanesi Pediatri Kliniği \\ Şirinevler Mahallesi, Adnan Menderes Cad.Sağlık Sok No:195, 54100 Adapazarı/Sakarya \\ T: +905335505351～E-mail: bahrielmas@gmail.com \\ Orcid \\ Bahri Elmas : http://orcid.org/0000-0001-9034-6109 \\ Gökçe Genç : https://orcid.org/0000-0001-8743-2778 \\ Taha Mansur Daştan : https://orcid.org/0000-0002-3825-7827
}

Geliş Tarihi / Received : 26-07-2019 Kabul Tarihi / Accepted : 05-08-2019 Yayın Tarihi / Online Published: 29-08-2019

Elmas B., Genç G., Daştan T.M., Dural Sinus Trombozu ile Seyreden Pediatrik Adenoviral Meningoensefalit Vakası J Biotechnol and Strategic Health Res. 2019;3(2):143-147 DOI: 10.34084/bshr.597186

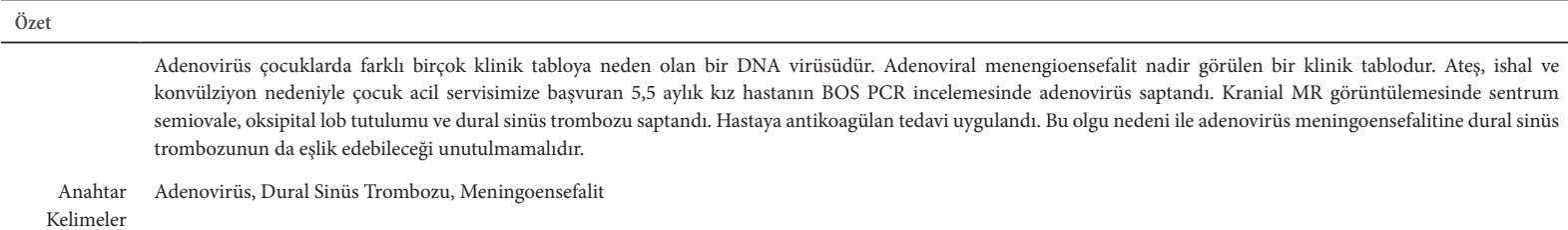

Adenovirus is a DNA virus that causes many different clinical features in children. Adenovirus meningoencephalitis is a rare clinical picture. Adenovirus was detected in CSF PCR of a 5.5-month-old girl who was admitted to our pediatric emergency department due to fever, diarrhea and convulsions. Cranial MRI revealed centrum semiovale, occipital lobe involvement and dural sinus thrombosis. The patient was treated with anticoagulants. It was emphasized that adenovirus encephalitis was accompanied by dural sinus thrombosis.

Keywords Adenovirus, Dural sinus thrombosis, Meningoencephalitis 


\section{GIIRIŞ}

Adenovirüsler küçük çocuklarda ateşli hastalıklara yol açan önemli bir virüs ailesidir ${ }^{1}$. Sıklıkla solunum yolu enfeksiyonu ile ilişkili olsa da gastrointestinal, oftalmolojik, genitoüriner enfeksiyonlara da neden olmaktadır ${ }^{2}$. Adenoviral hastalıkların çoğu kendi kendini sınırlar. Özellikle immün sistemi baskılanmış kişilerde ve nadiren de sağlıklı kişilerde ölümcül enfeksiyonlara neden olabilir. Nadiren oluşturduğu hastalıklar içinde aseptik menenjit, miyelit, ensefalit ve Reye benzeri sendrom sayılabilir ${ }^{3}$. Bu vaka sunumunda febril konvülziyon ön tanısı ile çocuk acil servisine başvuran ve beyin omurilik sıvısı (BOS) polimeraz zincir reaksiyonu (PCR) incelemesinde adenovirüs saptanarak viral meningoensefalit tanısı alan dural sinüs trombozlu hastamızı sunmayı amaçladık.

\section{OLGU SUNUMU}

Beş buçuk aylık kız hasta ishal ve ateşle birlikte nöbet geçirme nedeni ile çocuk acil servisimize getirildi. Fizik muayenesinde; bilinç uykuya meyilli, ateş $38,2^{\circ} \mathrm{C}$, solunum sayıs1 70/dk, kalp tepe atımı 160/dk, kan basinc1 $72 / 44 \mathrm{~mm} / \mathrm{Hg}$, deri turgoru azalmış, kapiller dolum zamanı uzamış, cutis marmaratus mevcut, ön fontanel bombe ve pulsatil, solunumu yüzeyel, dispneik ve takipneik, bilateral yaygin kaba ralleri mevcut idi. Laboratuvar incelemesinde pH 7.39, PCO2 $28.6 \mathrm{~mm} / \mathrm{Hg}, \mathrm{HCO} 3$ 19,4 mmol/L, glukoz $32 \mathrm{mg} / \mathrm{dL}$, laktat 5,8 mmol/L, lökosit sayısı 18,2 $\mathrm{K} / \mu \mathrm{l}$, nötrofil sayıs $5,82 \mathrm{~K} / \mu \mathrm{L}$, hemoglobin $10,2 \mathrm{gr} / \mathrm{dl}$, trombosit sayıs $54 \mathrm{~K} / \mu \mathrm{L}$, glukoz $30 \mathrm{mg} / \mathrm{dL}$, üre $55 \mathrm{mg}$ / $\mathrm{dL}$, kreatinin 0,6 mg/dL, sodyum $144 \mathrm{mmol} / \mathrm{L}$, potasyum 4,4 mmol/L, AST $232 \mathrm{U} / \mathrm{L}$, ALT $71 \mathrm{U} / \mathrm{L}$, ürikasit 8,8 mg/ $\mathrm{dL}$, CRP $4 \mathrm{mg} / \mathrm{L}$, prokalsitonin $200 \mathrm{ng} / \mathrm{mL}$, sedimentasyon $8 \mathrm{~mm} / \mathrm{saat}$, protrombin zamanı 19,3 sn, INR 1,82, aktive parsiyel tromboplastin zamanı 41,3 sn, fibrinojen $282 \mathrm{mg}$ / dL, D-dimer $1318 \mu \mathrm{g} / \mathrm{mL}$ (FEU) olarak saptandı. IgA, IgM ve IgG düzeyleri ile lenfosit alt grup değerleri normal bulundu. Kranial bilgisayarlı tomografi görüntülemesinde patoloji saptanmadı. BOS direkt bakıda her büyük büyütmede 10 lökosit ve 10 eritrosit sayıldı. Gram boyamada bakteri saptanmadi. BOS ve gaita PCR incelemesinde ad- enovirüs saptandı. Hastanın BOS kültüründe üreme saptanmadı. Kontrastlı kranial manyetik rezonans görüntülemesinde; oksipital alanda T2 hipointens düzensiz ve sentrum semiovalede hipointens düzensiz sahalar, post kontrast serilerde oksipital alanda ve sentrum semiovalede yoğun kontrast tutan giral yapılar saptandı (Resim 1).

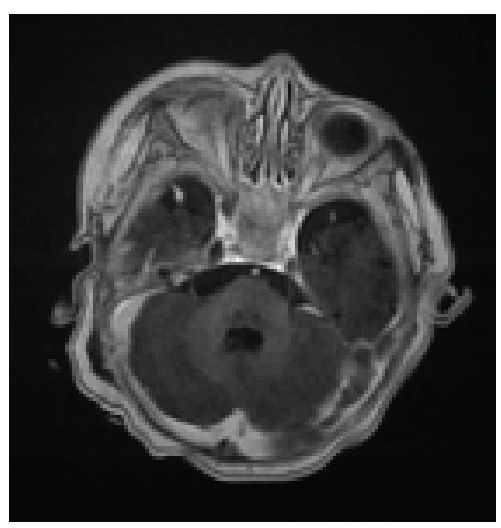

Resim 1. Oksipital alan ve sentrum semiovalede kontrast tutulumu, sol dural sinüs trombozu

Bulgular sol dural sinüs trombozu ile uyumlu olup oksipital gyrus yüzeyinde kortikal alanda hafif kanama ve meningoensefalit ile uyumlu idi (Resim 2).

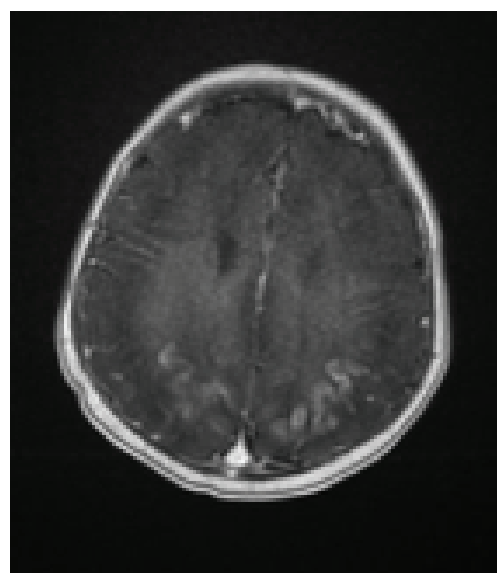

Resim 2: Sinüs ven trombozu

Elektro ensefalografik incelemede sol hemisferden başlayarak generalize olan keskin dalga aktivitesi saptand. Hasta entübe edilerek çocuk yoğun bakım ünitesine alındı 
ve mekanik ventilatöre bağlandı. İnotrop desteği başlandı. Ağır dehidrate olan hastaya üç kez $20 \mathrm{cc} / \mathrm{kg}$ serum fizyolojik yüklendi. Hipoglisemi nedeniyle bir kez 2 cc/kg \%10 dekstroz puşe uygulandı. $3 \mathrm{mg} \mathrm{K}$ vitamini intravenöz olarak yapıldı ve $10 \mathrm{cc} / \mathrm{kg}$ 'dan trombosit süspansiyonu verildi. Ampirik olarak seftriakson, vankomisin, klaritromisin ve oseltamivir başlandı. Herpes virüs enfeksiyonu dışlanamaması nedeniyle tedaviye asiklovir eklendi. Takiplerinde dirençli konvülziyonları olması nedeniyle $20 \mathrm{mg} /$ kg'dan fenitoin yükleme yapıldı ve midazolam infüzyonu başlandi. Nöbetleri kontrol edilemeyen hastaya pridoksin ve tiamin uygulanarak $20 \mathrm{mg} / \mathrm{kg}$ 'dan levetirasetam yükleme yapıldı ve ketamin infüzyonu başlandı. Venöz tromboz nedeniyle tedaviye enoksaparin eklendi. Takibinin dokuzuncu gününde nöbetleri kontrol altına alınan hasta ekstübe edilerek çocuk nöroloji ünitesi olan ileri bir merkeze sevk edildi. Sekelli olarak taburcu edilen hastanın takip ve tedavisi devam etmektedir.

\section{TARTIȘMA}

Adenovirüs farklı klinik tablolara neden olan, zarfsız, doğrusal, çift sarmallı bir DNA virüsüdür ${ }^{4}$. Üst solunum yolu enfeksiyonu, pnömoni, bronşiolit, konjonktivit, faringokonjonktival ateş, gastroenterit, invajinasyon, hemorajik sistit, menenjit, meningoensefalit gibi birçok klinik tablo oluşturabilmektir ${ }^{3-5}$. Meningoensefalit, adenovirüs enfeksiyonlarında nadir rastlanan bir klinik tablodur ${ }^{4}$. Vakalar izole meningoensefalit şeklinde görülebilmekle birlikte pnömoni ve gastroenteritin de sıklıkla eşlik ettiği bildirilmektedir ${ }^{6}$. Öksürük, baş ağrısı, ishal gibi nonspesifik bulguların yanında bilinç değişiklikleri ve konvülziyon gibi santral sinir sistemi bulguları da görülmektedir. Adenovirüs meningoensefalitine bağlı kompleks ve dirençli nöbetlerin olabileceği bildirilmektedir ${ }^{6,7}$. Ateş, ishal ve konvülziyon nedeni ile başvuran vakamızın takibinde dirençli nöbetler gözlenmiştir.

Çoğu meningoensefalit vakasında adenovirüsün BOS dışında diğer sistem materyallerinden saptandığı, BOS incelemesinde ise sıklıkla pleositoz bulunduğu bildiril- mektedir $^{3-11}$. Vakamızda ise gaita ile birlikte BOS incelemesinde de adenovirüs saptanmıştır. Ancak literatürdeki çoğu vakanın aksine BOS'da pleositoz saptanmamıştır. Ayrıca BOS biyokimya incelemesinde glukoz ve protein normal bulunmuştur.

Adenoviral meningoensefalit tansiyla takip edilen hastaların kraniyal görüntülemelerinde farklı bulgular olabileceği bildirilmektedir. Dubberke ve arkadaşları tarafından medulloblastom tanısıla takip edilen ve adenoviral meningoensefalit saptanan erişkin bir hastanın MR görüntülemesinde bilateral temporal lob tutulumu bulunduğu bildirilmiştir ${ }^{4}$. Schwartz ve arkadaşları tarafından adenovirüse bağlı ensefalit tanısı ile takip edilen sekiz çocuk hastanın MR incelemesinde talamus, substantia nigra, capsula interna, periventriküler beyaz cevher, bazal ganglion tutulumunun bulunduğu rapor edilmiştir ${ }^{6}$. Fianchi ve arkadaşları tarafından lenfoma tanısı ile takip edilen ve adenoviral meningoensefalit saptanan erişkin bir hastanın MR görüntülemesinde temporal lob ve insula tutulumunun saptandığı bildirilmiştir10. Tamiya ve arkadaşları tarafından yapılan çalışmada neonatal meningoensefalit tanısı alan 28 günlük bir hastanın MR görüntülemesinde talamus, internal kapsül ve korpus kallosum tutulumu saptandığı bildirilmiştir ${ }^{11}$. Vakamızda kranial MR incelemesinde sentrum semiovale ve oksipital lob tutulumuna ek olarak şu ana kadar literatürde bildirilmeyen sol dural sinüs trombozu saptanmıștır. Bu özelliği ile vakamız literatürdeki ilk pediatrik adenovirüs meningoenfesaliti vakasıdır.

Dural sinüs trombozunda tutulum bölgesine göre baş ağrısı, epileptik ataklar, dirençli konvülziyonlar ve koma gibi birçok klinik semptom görülebilmektedir ${ }^{12}$. Tedavide medikal olarak antikoagülanlar önerilmektedir ${ }^{13}$. Vakamızın takibinde de çoklu antikonvülzan kullanımı gerektiren dirençli konvülziyonlar gözlenmiştir. Tromboz tedavisinde ise düşük molekül ağırlıklı heparin kullanılmıştır.

Sonuç olarak; özellikle beş yaş altı çocuklarda farklı klin- 
ik tablolara yol açabilen adenovirüs enfeksiyonlarının meningoensefalit ile birlikte seyredebileceği ve uyum-

lu klinik bulguların bulunması durumunda dural sinüs trombozunun da eşlik edebileceği unutulmamalıdır. 
Journal of BSHR 2019;3(2):143-147

ELMAS, GEENÇ, DAȘTAN, Adenoviral meningoensefalit

\section{Kaynaklar}

1. Fox JP, Hall CE, Cooney MK. The Seattle Virus Watch. VII. Observations of adenovirus infections. Am J Epidemiol. 1977; 105(4): 362-386.

2. Lynch JP 3rd, Fishbein M, Echavarria M. Adenovirus. Seminars in Respiratory and Critical Care Med. 2011; 32(4): 494-511. doi: 10.1055/s-0031-128387.

3. Straussberg $R$, Harel L, Levy $Y$ et al. A syndrome of transient encephalopathy associated with adenovirus infection. Pediatrics. 2001;107(5): E69.

4. Dubberke ER, Tu B, Rivet DJ et al. Acute meningoencephalitis caused by adenovirus serotype 26. J Neurovirol. 2006; 12(3): 235-240.

5. Baskin E, Gokalp AS, Turkay S et al. Adenovirus gastroenteritis. Indian Pediatr. 1995; 32(10): 1128-1129.

6. Schwartz KL, Richardson SE, Mac Gregor D et al. Adenovirus-Associated Central Nervous System Disease in Children. J Pediatr. 2019; 205:130-137. doi: 10.1016/j.jpeds.2018.09.036

7. Reyes-Andrade J, Sánchez-Céspedes J, Olbrich P et al. Meningoencephalitis due to adenovirus in a healthy infant mimicking severe bacterial sepsis. Pediatr Infect Dis J. 2014; 33(4): 416-419.
8. Huang YC, Huang SL, Chen SP et al. Adenovirus infection associated with central nervous system dysfunction in children. J Clin Virol. 2013; 57(4): 300-304. doi: 10.1016/j. jvc.2013.03.017

9. Sakata H, Taketazu G, Nagaya K et al. Outbreak of severe infection due to adenovirus type 7 in a paediatric ward in Japan. J Hosp Infect. 1998; 39(3): 207-211.

10. Fianchi L, Scardocci A, Cattani P, et al. Adenovirus meningoencephalitis in a patient with large B-cellymphoma. Ann Hematol. 2003; 82(5): 313-315.

11. Tamiya $M$, Komatsu H, Hirabayashi $M$ et al. Neonatal meningoencephalitis caused by human adenovirus species F infection. Pediatr Int. 2019; 61(1): 99-101. doi: 10.1111/ ped. 13722

12. Bektaș H, Vural G, Temel Ș, ve ark. Serebral Sinus Venöz Trombozlu Hastaların Değerlendirilmesi. Ankara Üniversitesi Tip Fakültesi Mecmuası 2015; 68 (3): 107-110

13. Kaya D. The Diagnosis and Treatment of Cerebral Venous Thrombosis. Turk J Neurol 2017 23(3): 94-104. 